\title{
Theoretical and methodological principles of memorial parks three-dimensional composition and ideological lines expressing means complex assessment
}

\author{
Nadiia Oleksiichenko, Nadiia Gatalska, Mariana Mavko, \\ National University of Life and Environmental Sciences of Ukraine, Ukraine
}

\begin{abstract}
One of the aspects of the preservation of memorial parks as objects of cultural heritage, in the context of the formation of scientifically grounded approaches to the reconstruction of their territory, is the assessment of the present state of both the material components of the park space, and the features of the symbolism usage and means of expressing of their ideological load. On the basis of analysis of available techniques for evaluating individual components of the park space, the main aspect is the assessment of exclusively material elements of the park space - their qualitative, aesthetic and quantitative characteristics, and there is no differentiated approach to the evaluation in accordance with the functional features of the parks that limit the significance of one or another criteria. In addition, while using existing evaluation methods, symbols, ideologies, thematic orientation of the park, the stylistic unity of the composition, as well as the colour of park landscapes, which is an important means of highlighting its thematic orientation and its separate functional zones, evaluation of which in the park area is fragmentary in nature, remain out of focus. According to the results of the analysis of scientific sources of literature and researches of the Kyiv's memorial parks during 2011-2017, the newest methods for assessing the cultural and historical value and means of expressing the ideological load of memorial parks were developed, which include a system of criteria that characterizes both the common features, and the state of the components of the park space at the present stage are also the basis for forming directions for its further rational use.
\end{abstract}

Keywords: memorial park, ideological load, symbolics, assessment, functional colouring

\section{Introduction}

Parks during their history have been the synthesis of different arts and now they are centers of cultural and historic heritage of the country. The forms and content of gardens and parks has been changing along with the developing of society needs, which conditioned the transformation of the park space components. An important step of the park research is to analyze its formation and development characteristics and transformation of the territory during the whole period of their existence and the effects of these transformations. These are the keys for formation of optimal methods of park reconstruction and adaptation to modern conditions and promotion of conservation of valuable components of the park space.

Memorial complexes, as elements of urban environment, have a special general cultural significance that provides a connection with the past of the state, because they most fully illustrate the ideology through park space elements. Expression of the ideological load of memorial park due to composition elements, principles, and park landscape components, which are the base of park three-dimensional structure. At the same time, the transformational processes that are caused by park landscape development as a biological object irrevocably take place throughout the history of its existence.

The approaches and methods of park environment assessment have been highlighted in the works of a number of scientists, in particular: the aesthetic characteristics of landscapes and some components of park space were studied by Hrynasiuk [8], Hrozdynskyi \& Savytska [7], Kurdiuk [13], the subjective perception of park landscapes by Kaplan \& Kaplan [11], Kane [10], Forster [4], Kaymaz [12], Van Etteger et al. [23]. The functional approach to park space assessment is covered in the works of Oleksiichenko \& Gatalska [17], Oleksiichenko \& Mavko [21] and the conceptual scheme of the formation stages of the research program of the park environment aesthetics and their relationship was proposed (Oleksiichenko \& Gatalska [19]).

The problem of memorial park design was investigated by many scientists: Luntc [15], Likhachev [14], Bogovaia [2], Sokolskaia [22], Folkert [3], Janković [9], et al. However, we can hardly find complex scientifically based methodological thesis about the memorial parks research with considering on their peculiarities (in particular, the memorial function 
and cultural-historical significance) which would provide objective assessment of the current state and preservation level of parks and would be grounds for determination of optimal directions of their reconstruction for the purpose of rational management today.

Based on the analysis of both general and specific scientific approaches and methods of park environment assessment, it was revealed that, along with a large number of them, the analytical studies of symbolic-ideological and thematic orientation of the park, stylistic unity with composition elements and principles, and park landscape colouring remain outside the attention of the scientists.

The purpose of the research is to improve the park space assessment theoretical and methodological principles, in particular: to develop and substantiate theoretical innovation of complex approach to memorial park assessment and approbation of developed method during the Kyiv memorial parks assessment.

\section{Materials and Methods}

Four memorial parks of Kyiv are the objects of our research, in particular: the ones dedicated to famous figures ( $T$. Shevchenko Park and M. Rylsky Park in Holosiivo) and to war themes (Peremoha Park and Slavy Park). The results of complex surveys of their territory conducted during 2011-2017 became the actual materials for research. For the study we used general and specific scientific methods which were based on the environmental approach (natural surveys) and models using (graph-analytic studies, photophixation and photo analysis), historical information about the formation and development of parks were based on scientific literature sources and archival materials.

\section{Results}

According to scientific literature review and personal analysis of our researches of Kyiv memorial parks that were conducted during 2011 2017, the method of memorial park complex assessment was developed. It includes assessment of an object according to the following criteria divided into three groups. The first group includes the following criteria: availability of written information of formation and development of parks; the significance in the urban structure of settlement; the principle of placement in the urban structure of settlement.

Focusing on the substantiation of criteria separately as well as the results of parks assessment according to them, it is reasonable to begin with the availability of written information about the research objects in historical context. The materials that are needed for assessment according to the first criterion are: materials of historical project documentation, historical and archival materials (especially inventory information of different historical periods, with results of plant species diversity assessment which give a possibility to assess scientific, cultural and historical significance of park) and results of scientific literature analysis, and especially periodicals, which provide information about the significant events that took place on park territory, visits by prominent figures, memorable tree-planting etc.

The availability of written information of formation and development of parks criterion is scored the following way:

1 point - fragmentary data in the sources of information that are indirectly related to the object;

2 points - separate descriptive data in official sources of information on the time of creation, general features of the planning and threedimentional composition;

3 points - reliable descriptive data in the official sources of information above, as well as on development stages, designers, individual data on the composition of plants and other components of the park space;

4 points - comprehensive information provided by the previous criterion, as well as the availability of iconographic and cartographic materials of individual periods of development of the object, as well as data on the reconstruction (if any);

5 points - availability of reliable data (descriptive, cartographic, iconographic) for all stages of object development in various sources of information (scientific sources of literature, archival, project, etc.).

Assessment of the significance of memorial parks in the town-planning structure of the settlement (placement in settlement system and hierarchical level of urban-planning organization), scale, architectural and planning characteristics is important in the context of the overall development of the urban structure, which is in a constant transformation. At the same time, it is important to determine the historically formed image of the urban environment and the components that characterize it. The justification for the assessment based on this criterion is based on the classification of memorial objects by Sokolskaia [22]. The importance of this assessment is also highlighted by Janković [9].

The significance of memorial object in the urban structure of settlement criterion is estimated as follows:

1 point - the object covers a local area in a city, a populated area or in an interplastic area, which is not related to historical events, the memorial is dedicated to;

2 points - the property is located on the site of historical events, dedicated to, but has a small size 
and does not imply a general planning organization, of the area where it is located;

3 points - the object is an architectural or sculptural ensemble, occupies a certain territory, affects the planning organization of the administrative part of the settlement;

4 points - the object is a memorial-park or museum-memorial ensemble with a well-developed planning structure in the city or in the inter-peasant territory, which has a significant effect on the territory of the district in which it is located;

5 points - the object is a memorial-park, memorial-forest park or museum-memorial complex, which not only affects the planning and three-dimentional structure of the location, but defines it, subordinating the surrounding components of space.

A glaring example of the memorial and park complex is the "Slava" park in Kyiv, which according to this criterion is rated the highest point. The location of the object is not related to the historical events that it highlights, since its historical significance is not limited with the administrative districts of Kiev, but is connected with the history of the entire state, which is why the location in the city structure was chosen to emphasize the historical significance of the object. The highest score according to this criterion is Goloseevsky park named after M. Rylsky - occupies a considerable area $-140,9$ hectares and significantly influences the planning structure of Goloseevsky district.

A score of 4 points is given to Peremoha Park and to the park named after T. Shevchenko, whose influence on the urban environment is less than the above-mentioned objects. They are both memorialpark ensembles with a well-developed planning structure, which determines a significant influence on the territory of the district of its location.

The principle of placing in the structure of the settlement is an important classification mark, as well as a description of the memorial object, which corresponds or does not correspond to the historical events related to it. According to this criterion, it is possible to determine the expediency of placing an object in place and directions of further functioning. The theoretical basis for the formation of this criterion was the work of Lunts [15] and Sokolskaia[22].

Thus, the principle of placement in the urban structure of settlement criterion is scored the following way:

1 point - the object is located on the territory with which it is not connected, violates the integrity of the three-dimentional structure of the park territory;

2 points - the object is located in the territory with which it is not connected, but does not violate the compositional and ideological integrity of the territory it is located in;

3 points - the object is located in accordance with the town-planning principle of the placement of a memorial object;

4 points - the object is located in accordance with the historical documentary principle of the location of the memorial object;

5 points - the property is located in accordance with historical, documentary and town-planning principles.

An example of an object located in accordance with the historical documentary and town-planning principles can be Goloseevsky park named after M. Rylsky, placed according to town-planning and historical and documentary principles: during 1951-1964, near the northern edge of the park the Ukrainian poet M. T. Rilsky lived and worked on 7 M. Rylsky street, (currently - the museum).

The second group is formed by the criteria that characterize the compositional integrity of the memorial object - the correspondence of functional zoning and planning structure to the theme of the park, as well as the compositional integrity of the three-dimensional structure of the park.

Functional zoning of memorial parks has a number of features that are determined by their function and thematic orientation, which in turn affects the planning and three-dimensional structure of the park environment. Such circumstances determine the importance of assessment, the functional zoning and the planning structure of the memorial parks, analyzing their compliance with the thematic and ideological features of the object.

The correspondence of functional zoning and planning structure to the theme of the park criterion is estimated as follows:

1 point - the presence of functional areas that do not correspond to the theme of the park, as well as separate elements of the planning structure, which correspond to the ideology and style of the park (usually in the central part), however the integrity of their construction is absent;

2 points - the main functional zones and elements of the planning structure of the object, characteristic of the memorial parks, correspond to the stylistics of the park's space of the object, but the integrity of their composition is disturbed by the formation of secondary elements or functional zones that were formed during the existence of the park and are in the immediate vicinity of the central part;

3 points - the main elements of the central part of the planning structure of the object are characteristic of the memorial parks, correspond to the stylistics of the park space, the preservation of the main composite forests and prospects, 
the presence of all functional zones that must be located on the territory of the memorial parks, but their correlation is violated;

4 points - at the site there are all functional zones in the corresponding ratios, elements of the planning structure in the central part are characteristic of the memorial parks and correspond to the stylistics of the park space, the main composite axes and perspectives are preserved, however there are minor violations that are concentrated on the periphery of the park;

5 points - the planning structure of the object is an integral composition, in which all elements are subject to the thematic orientation of the park, emphasize the ideological and stylistic features of the three-dimensional structure, represent the indirect means of expressing the ideological load.

The importance of the analysis of functional zoning, among other things, is due to the results of the study of the memorial parks in Kyiv, during which it was discovered that some parks, besides the main one that was mentioned, perform several additional functions. For example, the Peremoha Park is characterized by a controversial combination of functions (memorial and entertainment), so it is estimated at 1 point. The "Slava" park, the functionalzoning of which is characterized by the presence of two different historical events of the memorial zones: the Memorial of the Eternal Glory with the obelisk on the grave of the unknown soldier and the Memorial to the Holodomor victims, dedicated to various historical events, but combined with the tragedy of these events. was evaluated as the highest among the researched objects by the score (4) according to this criterion. The only irrelevant functional component within the territory of this object is a children's playground located at a distance of about $50 \mathrm{~m}$ from the memorials.

The compositional integrity of memorial park is determined by its three-dimensional structure and affects the expression of thematic load also it is specific feature of each park. A prerequisite for objective assessment is the degree analisys of accordance of three-dimentional composition to park thematic. In addition, the definition of elements that violate the planning and compositional integrity of the park does not correspond to the subjects necessary for an objective assessment of its significance as a memorial object, as well as substantiation of rational directions for its reconstruction. The importance of defining disharmonious elements is emphasized by Ode, Tveit \& Fry [16], highlighting disharmony as a separate indicator that can act as a visual characteristic of the landscape.

The compositional integrity of the threedimensional structure of memorial park criterion is scored the following way:
1 point - chaotic placement of plants in the territory or solid masses without expressed composite integrity, discrepancy between the spatial organization of the theme of the park, the presence of separate components (in the central part), which emphasize the elements of the planning structure;

2 points - inconsistency of the general composition of plants with the themes and functions of the object as a memorial park, however, the presence of clearly expressed components of plantings (decorative groups, solitaries, curtains, etc.) and an agreed composition;

3 points - the composition of plants was formed during the laying of the park, but it has changed during the operation of the object. The presence in the central part of decorative groups, solitaries and other components of the spatial organization of the object, that characterize the period of the laying of relevant topics;

4 points - the composition of plants (mainly in the central part) corresponds to the theme of the park, there is a clear expression of the components of plantations and elements of spatial organization of the park, which, among other things, act as indirect means of ideological load;

5 points - the composition of plants is integral, all elements of its spatial organization are available, plantations along with the formation of the threedimensional structure of the memorial complex act as means of expressing the ideological load.

Describing the compositional integrity of research objects, one should pay attention to the Slavy Park, which is characterized by a panoramic compositional structure. The planning structure of the park is subordinate to the compositional dominant, which emphasizes its memorial purpose, in the memorial zone, the formal style, and the pleasur and the picturesque style are used. Present plantations emphasizing the ideological load of the park at the associative level - Sorbus aucuparia 'Pendula', Swida alba L. Opiz., Viburnum opulus L., Prunus divaricata 'Atropurpurea', Berberis thunbergii 'Atropurpurea'. Symbolic character is also given to cobblestone and small architectural forms, the rating according to this criterion of the park is at the level of 4 points.

The most voluminous is the study of the significance of the components of the threedimensional structure of a memorial object, the results of which are the basis for evaluation according to the criteria of the third group, which includes: colour accordance to park theme; state and value of architectural elements in disclosing park theme; state and value of paths paving and engineering equipment in disclosing park theme; compliance of flower design with the theme of the park; features of using means of expressing the ideological load of the park. 
One of the general stages of memorial park composition assessment is an analysis of its colour peculiarities, since colour has the greatest influence on psychological and emotional state of a person, it is a significant means in formation a comfortable environment depending on the functional purpose, ideological and thematic load and other features of the park object.

The importance of landscape colour in the context of memorial parks is a perspective area that would allow to form a purposeful environment depending on landscape objects functional peculiarities and ideological load of a park or a separate memorial. The criteria of colour accordance to park theme was evaluated by the following indicators: functional colours existence, their quantity; placement of functional colours (of main parks view-points in memorial zones); a colour bearers (their harmonization with the park environment in general); disclosure function by planting (during the year, colouring of plants). To calculate the quantitative indicators of park colouring, the method for assessing the colour of the landscape was used (Gatalska \& Mavko [5] Oleksiichenko et al. [18, 20]). The theoretical basis for the formation of this criterion were classifications of colour elements according to Abisheva [1], Georgberidze [6].

The colour accordance to park theme criterion is scored the following way:

1 point - functional colours are absent or present in small amounts which are pleaced chaotically; colour bearers are not a good combination with landscape; greenery has a monotone colouring;

2 points - functional colours are present in small amounts only in some view-points; colour beares are partially changeable or constant; plants do not expose functional colours;

3 points - functional colours are present in small amounts only in some view-points; non-solid colouring plants with short-term colouring are presented in park composition;

4 points - functional colours are present in large quantities in main view-points of memorial zone; all types of colour bearers are harmoniously included into landscape; non-solid colouring plants with longterm colouring are presented in park composition;

5 points - functional colours are present in large quantities in main view-points by all colour bearers; solid-colour plants with long-term colouring are presented in park composition.

The highest score on the criterion of correspondence to the colour theme of the park was not given to any of the research objects, and the The Slavy Park is the most relevant and is at 4 points, because in general it is a good example of the landcape coloring, and the coloring corresponds to its memorial function. Mostly because of achromatic colours of memorials (black $-3,4 \%$, grey $-24,0 \%$ ), white colour of the sky $(24,2 \%)$ and large quantity of green plants $(16,9 \%)$ and cool colours $(18,9 \%)$, whale quantity of other colours is small $(12,6 \%)$. There are fullcolored children playgrounds in the park that do not allow disclosing the park's memorial function, but they are located far away from memorial zone.

Architectural elements (monumental, decorative, utilitarian and etc.) as a rule are one of the main components of park composition. The main memorial often forms the basis of composition of park central part and sometimes of the whole park. A considerable number of architectural forms of utilitarian and decorative purposes, engineering structures, which should be included into the general composition and emphasize the park theme, are located on the memorial complex territory. The significance of the elements that directly or indirectly reveal the park theme are important in park architectural components assessment.

State and value of architectural elements in disclosing park theme criterion is estimated as follows:

1 point - the presence of only a central memorial that illuminates (directly or indirectly) the event which the park is dedicated to; the street furniture placement that are neutral or controversial;

2 points - the architectural elements of the park (monumental, decorative, utilitarian) emphasize the theme of the park, but they have significant damage and can not be used in accordance with the purpose without restoration work;

3 points - architectural elements have historical value and were created during the laying of the memorial complex, compositionally and ideologically subordinated to the main dominant, are in a satisfactory condition, their individual elements need restoration; it is permissible to have a small number of utilitarian utilization elements neutral to the subject matter;

4 points - architectural elements relate to the period of laying of the park, compositionally and ideologically are subordinated to the main dominant, are in good condition and perform all functions;

5 points - the affiliation of architectural elements (usually of the main memorial) to objects of cultural heritage, compositional and ideological coherence of all street furniture; architectural elements fully perform all functions and are means of expressing an ideological load, and their condition can be estimated as good.

As a result of the territory of experimental objects assessment, according to this criterion, a score of 4 points was awarded to the Slavy Park, within which the National Museum 
"Holodomor Victims Memorial" is located, which is one of the most successful examples of the use of small architectural forms for expressing the thematic load. The composition of the complex is formed on the central axis, which begins at the central entrance to the Memorial complex, on both sides of which there is a sculptural composition "Angels of Sorrow" - this is the embodiment of the soul guards of the deceased in the Holodomor.

This composition is a kind of "input portal" to the Memorial. It should be noted that the placement of buildings is quite good in the light of modern landscape park and its external environment, including the Kiev-Pechersk Lavra. All sculptures are in the content area of the museum dedicated to the victims of famine and have symbolic value and, thus, creating an extremely strong emotional impression that is reinforced by a gradual reading of the overall composition, the culmination of which is the monument "The Candle of Memory" - symbol of the Ukrainian people's memory about the tragedy. However, the main area is the dominant compositional obelisk that serves as a direct means of expressing the ideological load. In addition to individual monuments of individuals associated with the events of World War II, such memorial alleys are the emphasis on the park territory: Alley of Heroes, Alley of Soldiers Glory.

An example of a functional contradiction of architectural forms is the Peremoha Park, although it contains a lot of elements of the composition that directly express the content of the park theme. First of all, this is the Immortality Hill, buried from the ground brought from the soldier's graves, as well as the monument "Women of War", to the left of the sculptural composition - memorial tables, which are staged by the main events of the Second World War - are included in the composition of the entrance area of a park, a monument to the Widowed Mother near the Immortality Hill and the composition "People of the War". Also, as an accent in the northeastern part of the park there is a monument dedicated to the Border Guard's Alley. The composition of the alley consists of wooden columns, which are located at its beginning and are of a symbolic nature, a stone indicating the name of the thematic zone. At the end of the main alley a corner of military equipment, and in the western part - a stone wall with the name of the park. Accordingly, along with the saturation of the Peremoha Park thematic architectural elements revealed the street furniture, which contradict the theme of the park - playgrounds, attractions, trade pavilions, etc.

Elements of the path network (including staircases and ramps) and engineering equipment (retaining walls and lanterns) can, apart from utilitarian functions, be means for expressing an ideological load, which is an important aspect of emphasizing park theme. Paths paving may be a platform for creating symbolic inscriptions and themed patterns. Retaining walls can enhance the impression of the reliefs, forming a rhythmic composition; stairs can act as compositional line.

State and value of paths paving and engineering equipment in disclosing park theme criterion is scored the following way:

1 point - the presence of elements of engineering equipment in the central part of the object (near the main memorial), which do not emphasize, but do not contradict the theme of the park, are in a satisfactory condition and perform their functions;

2 points - the paths paving and elements of the engineering equipment are available in sufficient quantity in the territory of the memorial object and are in good condition, however, they do not emphasize the theme of the park, but do not contradict it;

3 points - the paths paving and elements of engineering equipment, in addition to the main functions, act as means of expressing the ideological load of the park, emphasize the style of the main memorial and the park space as a whole, but have certain damages and require repair and restoration works;

4 points - the paths paving and elements of engineering equipment fully perform utilitarian function, emphasize the stylistics of the main memorial and the park space in general, are in good condition, do not require repair and restoration, on the periphery, it is allowed to place elements requiring minor repair and restoration works;

5 points - the elements of the paths paving and elements of engineering equipment are located throughout the park, fully perform utilitarian functions and emphasize the stylistics of the main memorial and park space in general, are in good condition

The "Memory arable land" paving and other and ornamental paving the territory of Holodomor Victims Memorial are one of the most successful examples of park theme load, which are reproduced in the paths paving (Fig. 1). That is why Slavy Park and Peremoha Park are given 5 points by this criterion. Peremoha Park has a linear composition of the path network. Most of the park's paths are made of paving the gray colour, and in the memorial and exposition zones there is a specific design of path paving with a different compositional solution, according to park theme.

Flowers are important components of the park space, they emphasize the theme of the memorial park or complex, complete the composition, and sometimes increase the emotional influence of the main memorial. It is important to mention that flowerbeds in a memorial park, which are created 
only for aesthetic purposes, usually do not play an important role in revealing the ideological load, and sometimes contradict it and disturb the compositional integrity of an object (Fig. 2). The most valuable are parterres and flowerbeds located near the main memorial, which, emphasizing its style and increasing the emotional impact on a person, can act as indirect means of expressing an ideological load.

Accordingly, the assessment of compliance of flower design with the theme of the memorial park can be made as follows:

1 point - in the absence of a flower design, but the presence of a lawn on the whole territory of the park in good condition. The score can be lowered to 0 points if the flower registration contradicts with the theme of the park and the lawn condition is unsatisfactory;

2 points - flower design is available only in the central part, but the themes of patterns and species composition of plants are exclusively decorative in nature;

3 points - flower design corresponds to the theme of the park, only in the central part, while throughout the park flower beds perform only a decorative function;

4 points - flower design throughout the territory improves the decorative qualities of the park space, the overall compositional solution is consistent with the theme of the park, but the periphery of the flower beds are exclusively decorative in nature;

5 points - parterres and flower beds located near the main memorial, emphasize its style and enhance emotional affect and act as indirect means of expressing an ideological load. In addition to the central part, they are placed near the composite accents, where the emotional impact of the main memorial is weakened.

Thus, the final stage is to determine the means of expressing the ideological loading of the park both direct and indirect (Fig. 3, 4, Table 1). In particular, the features of using means of expressing the ideological load of the park criterion is scored the following way:

1 point - presence of the main memorial element - a monument, a memorial plaque, a memorial sign, etc. as a direct means of expressing an ideological load;

2 points - the presence, besides the basic, of additional means of expressing the ideological load, which necessarily emphasize its meaning and are related to the theme of the park;

3 points - the usage of indirect means (plantations, relief, paving elements) in the composition of the memorial park, in addition to direct means of expressing the ideological load, which are located in different parts of the territory and emphasize the thematic orientation of the park, however, do not create an integral composition;

4 points - the presence and justified usage in the composition of the park space of direct and indirect means of expressing ideological load, mainly in the central part of the memorial complex;

5 points - the compositional construction of the park's territory is an inseparable synthesis of all elements of the park space, which are both direct and indirect means of expressing the ideological load, are subordinated to the dominant and fully reveal the idea and thematic orientation of the park space at the ideological, compositional and emotional levels.

After conducting the assessment based on the criteria and determining the total number of points, the objects can be divided into groups which characterize the current state and directions of rational using of the park as a memorial object: the most valuable memorial parks (50-35 points) - can function as memorial-historical museums, memorial parks, need measures aimed at their preservation; the valuable memorial parks (34-21 points) - it is necessary to create a project for park reconstruction, the scale of which is determined in accordance with elements that destroy its compositional and ideological integrity; the low value in memorial aspect parks (20-15 points) - restoration of the park for use as memorial park is quite labor-intensive, primarily because of significant damage to all elements of park space. For rational use of park territory it is necessary to determine the possibility of adapting the park to modern conditions without or with the change of its memorial functions; have no memorial and cultural-historical value (14 or less points) - restoration of park composition in general as a memorial park is inappropriate, since most elements of park space do not accord with memorial theme and do not have culturalhistorical or architectural value. If the place of memorial park is connected with historical events to which it was dedicated, it is impossible to transfer the memorial, but the park must be adapted to modern needs of the society, and the memorial elements must be localized in separate functional zone.

Summarizing the results of complex assessment of research parks (Fig. 5), the most valuable memorial park is the Slavy Park (42 points), the rest belong to valuable memorial parks: Peremoha Park (33 points); T. Shevchenko Park (34 points); M. Rylsky Park in Holosiivo (29 points).

Analyzing the results of assesment research objects according to individual criteria, one should pay attention to the unused potential of flower decorations 


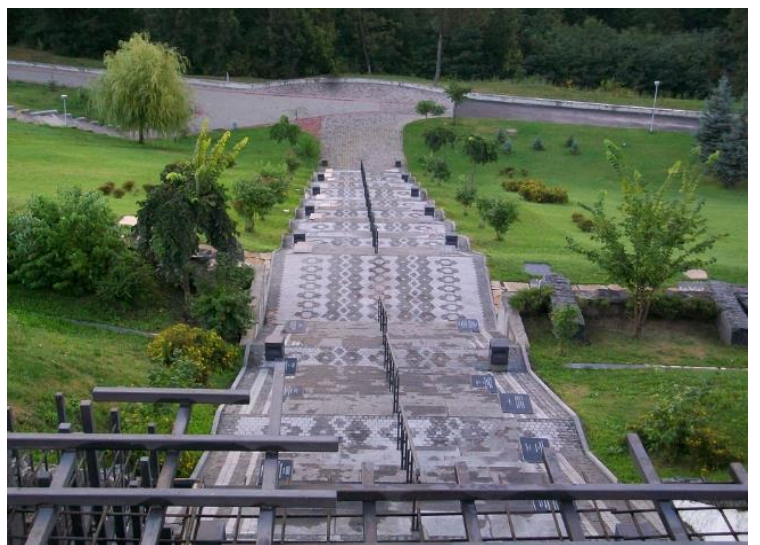

Fig. 1. Paving with Ukrainian ornament on the territory of Holodomor Victims Memorial (Slavy Park)

[photo by the authors, 2015]

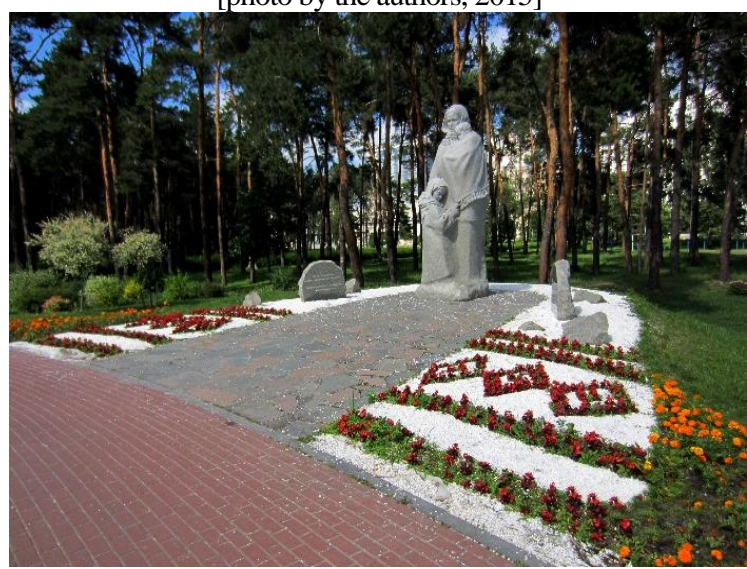

Fig. 2. Themed flowerbed at the monument "Widowed Mother" in Peremoha Park [photo by the authors, 2016]
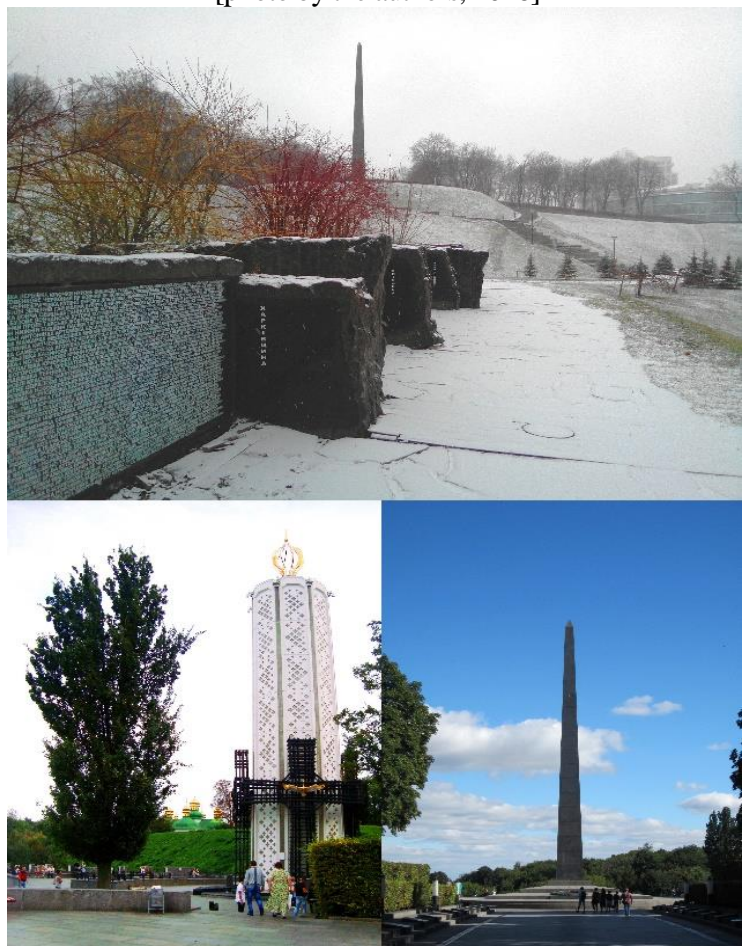

Fig 3. Direct means of expressing ideological load of the Slavy Park ("Black boards" Alley; "Candle of Memory"; Memorial of Eternal Glory) [photos by the authors, 2014-2017]

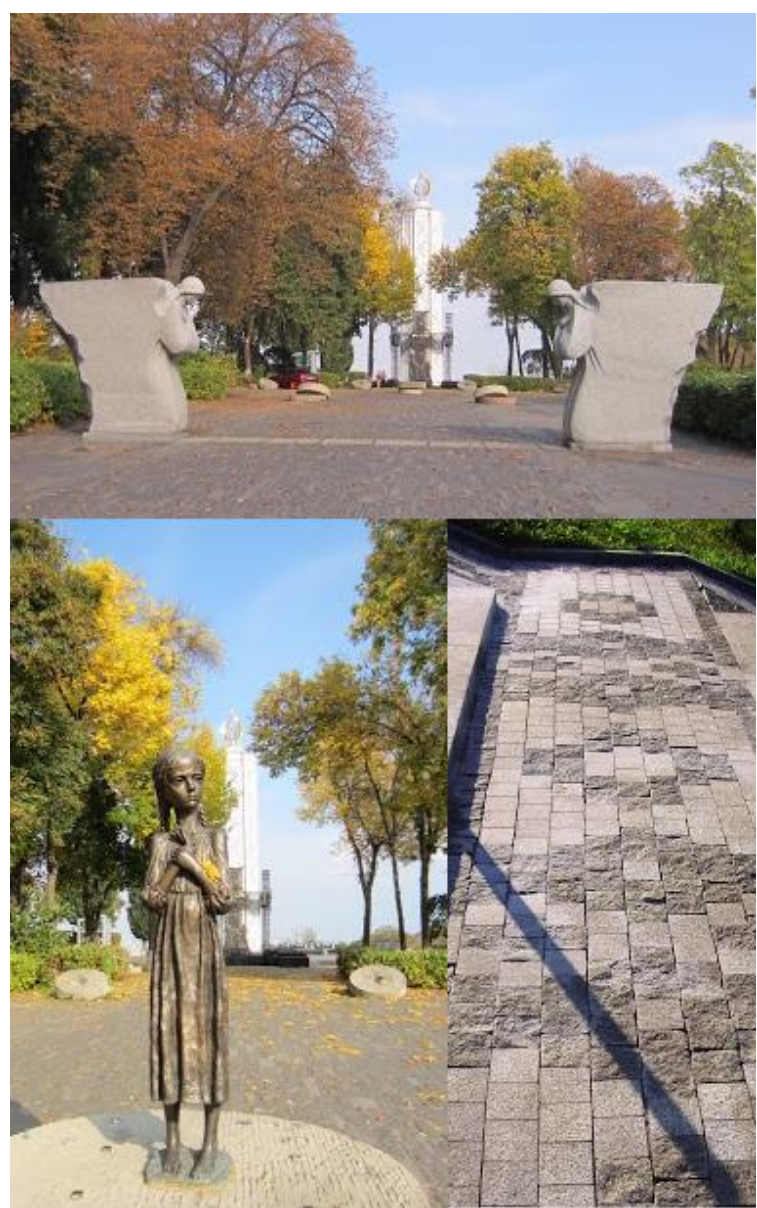

Fig. 4. Indirect means of ideological load expression of the Slavy Park (symbolic sculptures "Angels of grief"; symbolic sculpture of girl with five spikes; symbolic paving) [photos by the authors, 2014-2017]

in the Slavy Park as a means of expressing the ideological load and underscoring its stylistics, the inappropriate location of the playground and the need to improve the composition of the plantings.

For functioning and rational use of the Peremoha Park and T. Shevchenko Park at the present stage it is necessary to carry out further research and create projects for the reconstruction of the park space, the scale of which is determined in accordance with elements that violate their compositional and ideological integrity. In particular, the main problem of the T. Shevchenko Park is a chaotic placement of plantations, the controversy of flower design and a significant number of street furniture, which do not correspond to the functional purpose of the park and are not consistent stylistically neither with the main memorial nor with each other.

An important component that contributes disharmony to the composition of the park are flowerbeds arrangements, the configuration of which changes annually and, as a rule, contradicts the theme of the park. In addition, in the Peremoha Park, along with a number of elements that directly and 
The means of expression of the ideological loading in memorial parks that are dedicated to war themes [created by the authors, 2018

\begin{tabular}{|c|c|c|}
\hline Objects & Direct means of expressing ideological load & Indirect means of expression ideological load \\
\hline & $\begin{array}{l}\text { - National Museum "Memorial to } \\
\text { Holodomor Victims"; } \\
\text { • Memorial of Eternal Glory; } \\
\text { - "Candle of Memory" in the center of } \\
\text { Holodomor Victims Memorial; } \\
\text { • monuments: monument of I. Kozhedub, } \\
\text { L. Bykov; } \\
\text { - memorable alley: Alley of Heroes, Hero } \\
\text { Cities Alley, Alley of Glory soldiers, "Black } \\
\text { boards" Alley. }\end{array}$ & $\begin{array}{l}\text { - sculpture of girl with five spikes; } \\
\text { - symbolic paving; } \\
\text { - symbolic sculpture "Angels of grief", "millstones of } \\
\text { history" in the entrance of Holodomor Victims Memorial and } \\
\text { other architectural forms; } \\
\text { - relief (panoramic composition); } \\
\text { - planting (winding, purple, pyramidal shape) namely Sorbus } \\
\text { aucuparia 'Pendula', Swida alba L. Opiz., Viburnum opulus } \\
\text { L., Prunus cerasifera subsp. pissardii Dost, Berberis } \\
\text { thunbergii 'Atropurpurea', Malus niedzwetzkyana Dieck., } \\
\text { Berberis vulgaris 'Atropurpurea'. }\end{array}$ \\
\hline $\begin{array}{l}\text { Peremoha } \\
\text { Park }\end{array}$ & $\begin{array}{l}\text { • mound of Immortality; } \\
\text { - monument "Women of War", monument of } \\
\text { Mother Widow; } \\
\text { - memorial plaques, information stones. }\end{array}$ & $\begin{array}{l}\text { - remains of entrenchments (historical relief); } \\
\text { - some planting (Betula pendula 'Youngii' in memorial zone } \\
\text { of park, Borderguards Alley with Populus bolleana Louche); } \\
\text { - thematic flower design (parterres, rock garden). }\end{array}$ \\
\hline
\end{tabular}

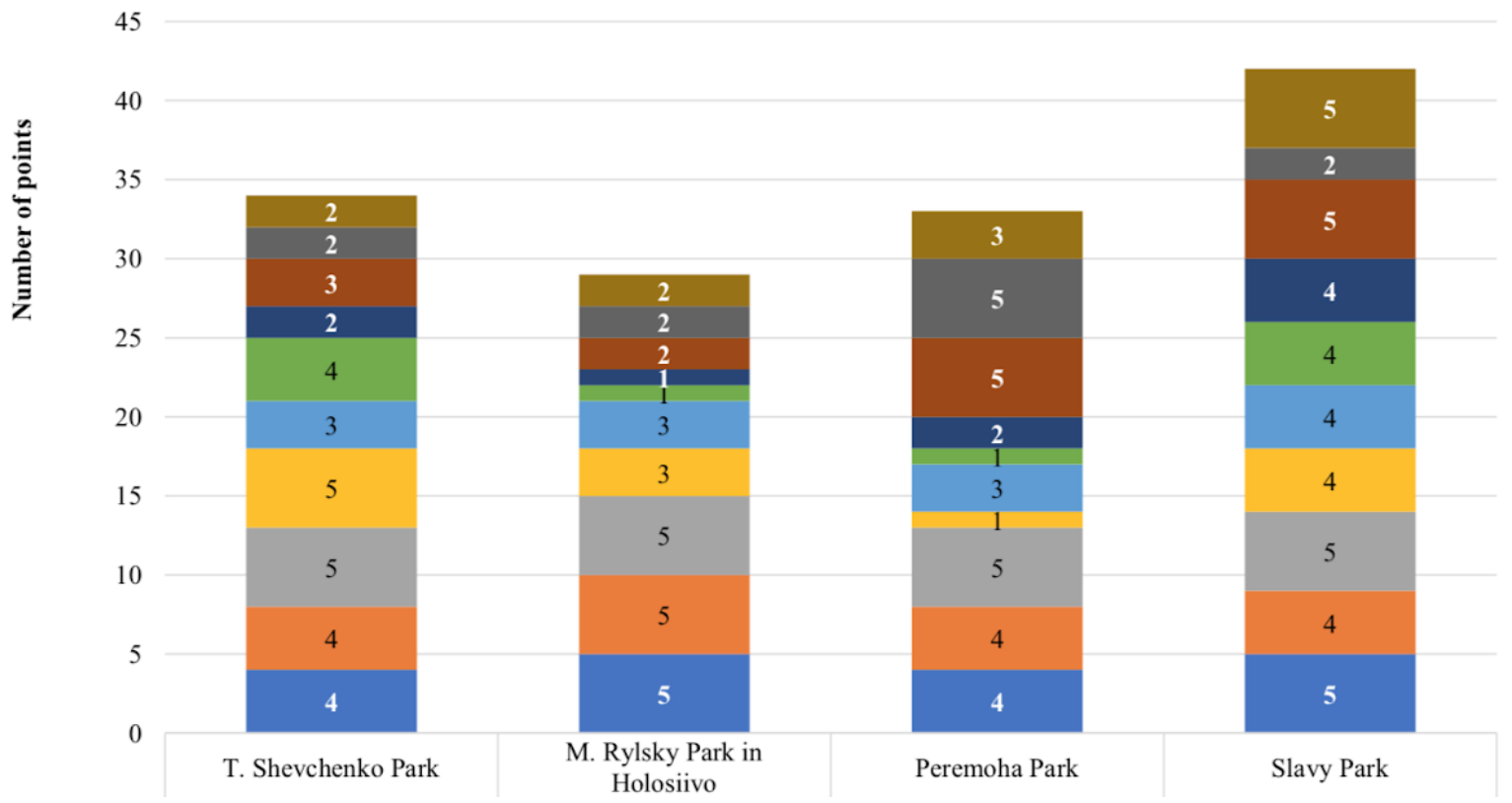

10. Features of using means of expressing the ideological load of the park

घ. Compliance of flower design with the theme of the park

- 8. State and value of paths paving and engineering equipment in disclosing park theme

- 7. State and value of architectural elements in disclosing park theme

6. The colour accordance to park theme

m5. The compositional integrity of the three-dimensional structure of the park

4. The correspondence of functional zoning and planning structure to the theme of the park

3. Availability of written information of formation and development of parks

=2. The principle of placement in the urban structure of settlement

- 1 . The significance in the urban structure of settlement

Fig. 5. Results of integrated assessment of research facilities [created by the authors, 2018] 
indirectly emphasize the theme of the park and reveal the ideological load, there are entertaining attractions that largely neutralize the influence of thematic elements and violate the integrity of the three-dimentional composition. In particular, to recreate it and focus on the theme of the park, it is necessary to visually separate the entertainment elements from the memorial ones. One of the solutions can be the separation of entertainment and children's areas and the organization of a family holiday park, which should be solved at the legal and organizational levels.

The main problems of the M. Rylsky Park is the discrepancy between the planning structure and functional zoning, the architectural elements of the theme and park stylistics, flower arrangement. This discrepancy is caused by the fact that the components of park space of the M. Rylsky Park was formed to meet the recreational needs, the memorial function was small, probably secondary. Nowadays the park is important as a center of recreation and an element of natural forests of Goloseyevsky forest, but the memorial function is not sufficiently expressed.

\section{Conclusions}

One of the aspects of the preservation of memorial parks as objects of cultural heritage, in the context of the formation of scientifically grounded approaches to the reconstruction of their territory, is the assessment of the present state as the material components of the park space, and the features of the use of symbolism and means of expressing their ideological load.
On the basis of analysis of available techniques for evaluating individual components of the park space, the main aspect is the assessment of exclusively material elements of the park space - their qualitative, aesthetic and quantitative characteristics, and there is no differentiated approach to the evaluation in accordance with the functional features of the parks that limits the significance of one or another criteria. In addition, while using existing evaluation methods, symbols, ideologies, thematic orientation of the park, the stylistic unity of the composition, as well as the colour of park landscapes, which is an important means of highlighting its thematic orientation and its separate functional zones, whose evaluation currently is fragmentary in nature, remains out of focus.The newest methods for assessing the cultural-historical value and means of expressing the ideological load of memorial parks are developed, which include a system of criteria that characterizes both general features and the state of the components of park space at the present stage and is the basis for forming directions for its further rational use.

The evaluation of the memorial park carried out according to the recommended criteria can characterize the general features of the park, the degree of preservation at the present stage and become the basis for forming directions for its reconstruction.

\section{References}

1. Abisheva, S. I. Colour theory [Cvetovedenie]. Pavlodar: Pavlodar State University publishing, 2009. 116 p. (in Russian)

2. Bogovaia, I. O., Teodoronskiy, V. S. Landscaping of inhabited places [Ozeleneniye naselennykh mest]. Moscow: Agropromizdat, 1990. 239 p. (in Russian)

3. Folkert, T. Landscape as memory. Journal of Landscape Architecture, 2015, vol. 10 (1), p. 68-77. doi: $10.1080 / 18626033.2015 .1011445$

4. Forster, P. M. A brief introduction to environmental psychology [online 01.04.2018.]: http://www.academia. edu/2201388/An_introduction_to_environmental_psychology

5. Gatalska N., Mavko M. Assessment of landscape colour peculiarities. Agrobiology, 2012, vol. 8 (94), p. 54-57. (in Ukrainian).

6. Georgberidze, D. I. Colour of tree plants and its significance in landscape architecture [Okraska drevesnykh rasteniy i yeye znacheniye v landshaftnoy arkhitekture]. Tbilisi: Metsnireb, 1979. 35 p. (in Russian)

7. Hrozdynskyi, M. D., Savytska, O. V. Landscape aesthetics [Estetyka landshaftu]. Kyiv: Polihraftsentr «Kyivskyi universytet», 2005. 183 p. (in Ukrainian).

8. Hrynasiuk, A. R. Methodical bases for assessing the attractiveness of landscapes [Metodychni osnovy otsinky atraktyvnosti landshaftiv]. Pryroda Zakhidnoho Polissia ta prylehlykh terytorii, 2014, vol. (11), p. 132-135. (in Ukrainian).

9. Janković, N. Architectural Terri(s)tories: Jajinci Memorial Park in Belgrade. Journal of Art and Media Studies, 2017, № 12, p. 81-97. doi: 10.25038/am.v0i12.169

10. Kane, Ph. S. Assessing landscape attractiveness: a comparative test of two new methods. Applied Geography, 1981, vol. 1(2), p. 77-96. https://doi.org/10.1016/0143-6228(81)90027-8

11. Kaplan, S., Kaplan, R. Humanscape - environments for people. North Scituate, Mass.: Duxbury Press, 1978.480 p.

12. Kaymaz, I. C. Landscape Perception. In: Landscape Planning, Rijeka: InTech, 2012, chapter 12, p. 251-276. doi: $10.5772 / 38998$

13. Kurdiuk, M. G. To the question of assessing the decorative effect of park plantings [K voprosu otsenki dekorativnosti parkovykh nasadzheniy]. Preservation and restoration of ancient parks, 1982, p. 65-68. (in Russian)

14. Likhachev, D. S. Reconstruction of Cultural Monuments: Problems of Restoration [Vosstanovleniye pamyatnikov kul'tury: Problemy restavratsii]. Moscow: Iskusstvo, 1981. 232 p. (in Russian) 
15. Luntc, L. B. Urban green building [Gorodskoye zelenoye stroitel'stvo]. Moscow: Stroyizdat, 1974. 280 p. (in Russian)

16. Ode, A., Tveit, M. S., Fry, G. Capturing landscape visual character using indicators: Touching base with landscape aesthetic theory. Landscape Research, 2008, vol. 33 (1), p. 89-117. doi:10.1080/01426390701773854

17. Oleksiichenko, N. O., Gatalska N. V. Parks-monuments of landscape art of the Central Pridniprovsky highland area [Parky-pamyatky sadovo-parkovoho mystetstva Tsentral'noprydniprovs'koyi vysochynnoyi oblasti], monograph, part 1. Kyiv: CP COMPRINT, 2012. 146 p. (in Ukrainian).

18. Oleksiichenko, N. O., Gatalska, N. V., Mavko, M. S. Scientific basis of assessment of park current state and preservation [Naukovi osnovy otsinyuvannya suchasnoho stanu ta rivnya zberezhenosti parkiv], recommendations for Ukrainian enterprises in the field of landscape gardening, landscape architecture and urban planing. Kyiv: NUBiP, 2016. 51 p. (in Ukrainian)

19. Oleksiichenko, N. O., Gatalska N. V. Theoretical aspects of the functional purpose of parks as the basis for the formation of approaches for aesthetical qualities assessment of park environment. Proceedings of the forestry academy of sciences of Ukraine, 2017, vol. 15, p. 73-81. (in Ukrainian, with English abstract).

20. Oleksiichenko, N. A., Mavko, M. S. The assessment approaches to analyse landscape colour. Scientific Bulletin of UNFU, 2013, vol. 23.9, p. 65-69. (in Ukrainian, with English abstract).

21. Oleksiichenko, N. A.; Mavko, M. S. Functional features and landscape coloring of memorial parks in Kyiv. Scientific herald of NULES of Ukraine (Forestry and decorative gardening), 2015, № 229. p. 186-192. http://nbuv.gov.ua/UJRN/nvnau_lis_2015_229_28. (in Ukrainian, with English abstract).

22. Sokolskaia, O. B., Teodoronskiy, V. S., Vergunov, A. P. Landscape architecture: specialized objects [Landshaftnaya arkhitektura: spetsializirovannyye obyekty]. Moscow: Publishing Center "Akademiya", 2007, p. 173182. (in Russian)

23. Van Etteger, R., Thompson, I.H., Vicenzotti, V. Aesthetic creation theory and landscape architecture. Journal of Landscape Architecture, 2016, vol. 11 (1), p. 80-91. doi: 10.1080/18626033.2016.1144688

INFORMATION ABOUT AUTHORS:

Nadiia Oleksiichenko - Doctor of Agricultural Sciences, Professor, Professor at the Landscape Architecture and Park-Garden Construction Department of National University of Life and Environmental Sciences of Ukraine, 19 Heneral Rodimtsev str., 03041, Kyiv, Ukraine. E-mail: noolex@ bigmir.net.

Nadiia Gatalska - PhD of Agricultural Sciences, Associate Professor at the Landscape Architecture and Park-Garden Construction Department of National University of Life and Environmental Sciences of Ukraine, 19 Heneral Rodimtsev str., 03041, Kyiv, Ukraine. E-mail: gatalska@ukr.net.

Mariana Mavko - Master of Park Gardening, PhD student of Landscape Architecture and Park-Garden Construction Department of National University of Life and Environmental Sciences of Ukraine, 19 Heneral Rodimtsev str., 03041, Kyiv, Ukraine. E-mail: marianna.kotsan@gmail.com.

Kopsavilkums. Viens no pieminekḷu parku kā kultūras mantojuma objektu saglabāšanas aspektiem ir parka telpas sastāvdalıu pašreizējā stāvokḷa novērtējums, un simbolikas izmantošanas pazīmes, un to ideologiskās slodzes izteikšanas līmenis. Pamatojoties uz pieejamo tehnisko paņēmienu analīzi, lai novērtētu parka telpas atsevišķās sastāvdalas, galvenais aspekts ir parka telpas atsevišḳo elementu novērtējums. Nepastāv atškirīīgas pieejas parku vērtēšanai, kas ierobežo viena vai otra kritēija nozīmi. Izmantojot esošās vērtēšanas metodes, simbolus, ideoloǵijas, parka tematisko orientāciju, kompozīijas stilistisko vienotību, kā arī parku ainavas krāsu, tiek iegūta sagatave parku detālam pētījumam. Saskaņā ar zinātnisko literatūras avotu analīzes rezultātiem un Kijevas piemiṇas parku pētījumiem 2011.-2017. gadā tika izstrādātas parku ideologiiskās slodzes novērtēšanas metodes. Tostarp radīta kritēriju sistēma, kas raksturo gan kopējās iezīmes, gan parka vietas sastāvdalıu stāvokli pašreizējā posmā, tā veidojot virzienus parku turpmākajai racionālai izmantošanai.

Parki savas vēstures laikā ir bijuši dažādu mākslu sintēze, un tagad tie ir valsts kultūras un vēsturiskā mantojuma centri. Dārzu un parku formas un saturs ir mainījies līdz ar sabiedrības vajadzību attīstîbu, kas noteica parka galveno komponentu pārveidošanu. Parku pētījuma pamatā ir analizēta to veidošanās un attīstība, un šo transformāciju procesu sekas. Izvērtējot minētos datus, tiek izveidotas optimālas parku rekonstrukcijas metodes, pielāgojoties mūsdienu apstākḷiem, tā popularizējot parka telpas vērtīgāko komponentu saglabāšanu.

Piemiṇas memoriāla kompleksam kā pilsētvides elementam ir īpaša kultūrvēsturiskā nozīme, kas nodrošina saikni ar valsts pagātni, ilustrējot politisko ideolog̣ijas laiku. Piemiņas parka ideolog̣iskā izpausme kompozīcijas elementos, veido parka trīsdimensiju struktūru. Tajā pašā laikā transformācijas procesi, kurus izraisa parka ainavas attīstība kā bioloǵisks objekts, neatgriezeniski notiek visā parka pastāvēšanas vēsturē.

Pētijuma mērķis ir uzlabot parku telpas novērtējuma teorētiskos un metodologiskos principus, izstrādājot kompleksās pieejas teorētiskos jauninājumus memoriālā parka novērtēšanā un metodes aprobācijā.

Pētijumu objekti ir četri Kijevas memoriālie parki: veltīit pazīstamiem cilvēkiem (T. Ševčenko parks un M. Rylsky parks Holosiivos) un kara tēmām (Peremoha parks un Slavy parks). 2011.-2017. gadā veikto teritoriju apsekojumu rezultāti kḷuva par pētījumu materiāliem. Pamatā tika izmantotas zinātniskās metodes dabas apsekojumi, modelēšana ar grafiskās analīzes pêtījumiem, fotofiksācijas un foto analīze, zinātnisko literatūru avoti un arhīvu materiāli. 